\title{
CECÍLIA E OS 40 FANTASMAS E AVENTURA DO LOBO: PROCESSO CRIATIVO E DRAMATURGIA PARA CRIANÇAS
}

\author{
CECÍLIA E OS 40 FANTASMAS E AVENTURA DO LOBO: \\ CREATIVE PROCESS AND DRAMATURGY FOR CHILDREN
}

\author{
Necylia Maria da Silva Monteiro*
}

Resumo: Pretende-se apresentar nesta escrito, que se desenvolve dentro do panorama das metodologias de pesquisa em arte, o processos de escrita dos espetáculos Aventura do Lobo e Cecília e os 40 fantasmas criando uma narrativa/relato firmada em diálogos teóricos onde a autora reflete sua própria prática de pesquisa e processo formativo em dramaturgia. Há na natureza da criação desses textos a reflexão sobre o fazer teatral para crianças e seus contextos de montagem e recepção teatral. Aqui dialoga-se a autoria em movimento através da prática do dramaturgista, quando o texto se constrói em sala de ensaio vinculado aos atores e a encenação evocando uma performatividade ao processo.

Palavras Chave: Dramaturgia. Experiência. Processo criativo. Teatro para crianças.

\begin{abstract}
This article aims to present in this article, which is developed within the panorama of the methodologies of research in art, the writing processes of the shows Aventura do Lobo and Cecília e os 40 fantasmas creating a narrative / narrative signed in theoretical dialogues where the author reflects his own practice of research and formative process in dramaturgy. There is in the nature of creation of these texts the reflection on the theatrical doing for children and their contexts of theatrical assembly and reception. Here dialogues the authorship in movement through the practice of the dramaturgista, when the text is constructed in test room linked to the actors and the staging evoking a performativity to the process.
\end{abstract}

Keywords: Dramaturgy. Experience. Creative process. Theater for children

\section{Introdução}

Pouco sabemos sobre o que move as crianças em direção a determinada peça, texto literário ou filme. A maneira que cada criança se relaciona e constrói sentido sobre suas experiências artísticas é território ainda pouco explorado, e por isso deve-se acreditar na diversidade de obras de arte para as pequenas, e na importância de se debater o assunto em universidades e espaços aos quais compete debater sobre outras artes.

Antes, na perspectiva "adultocêntrica" de organização social ${ }^{1}$, a criança era vista apenas como um ser passível e improdutivo. Agora ela consome cultura e até produz. Porém, a mercê das escolhas feitas por adultos, pais e professores que as fazem na maioria das vezes sem critérios estéticos, considerando apenas preços, aspectos mais visíveis (superficiais até) ou mesmo guiados pela memória emotiva de suas próprias infâncias que anulam qualquer senso crítico. (LEÃO, 2001).

\footnotetext{
* Artista maranhense de Teatro e Circo, mestranda no Programa de Pós Graduação Artes da Cena (ECOUFRJ) E-mail: necyliamonteiro@hotmail.com

${ }^{1}$ Nos estudos de Edmir Perrotti (1984) sobre a criança e a produção cultural é abordada a categorização rígida do adulto como um ser ativo e da criança como um ser passivo sob a ótica do sistema de produção capitalista, que determina e reconhece um segmento no todo social pela sua atividade ou ausência dela. Perrotti afirma que essa oposição ativo/passivo, referindo-se à criança e ao adulto é histórica e não natural, interferindo no fato de que pouco se pensa na criança produzindo cultura ou recebendo e produzindo cultura ao mesmo tempo.
} 
Em uma importante e oportuna pesquisa que se concentrou na dramaturgia para crianças da década de setenta em São Paulo, Maria Lúcia de Souza Barros Pupo (1991) se propôs a analisar tais dramaturgias em diversos aspectos. Tanto quantitativos, na categorização dos aspectos comuns nos textos, quanto qualitativos, elucidando aspectos peculiares de cada texto tais como maniqueísmos (dicotomia entre o bem e o mal), didatismos (exposições de qualquer tipo) e estereótipos (situação de emissão de preconceitos, lugares comuns ou frases feitas), sendo nesse momento a abordagem qualitativa de maior utilidade, uma vez que tange discussões acerca do texto teatral e suas especificidades.

Nos recursos dramáticos, por exemplo, Pupo (1991) menciona a presença maciça da música e da comicidade, tidos como "elementos incorporados ao conceito daquilo que o adulto entende como sendo o gosto infantil, que parece inconcebível a criação de um texto teatral desprovido do seu emprego" (p. 100), restringindo a comicidade apenas a "incidentes que pretendem provocar riso".

Outro recurso dramático elencado, presente nas dramaturgias analisadas, são o envolvimento do público e a explicitação da convenção teatral, para além de tentativas de aproximação com a plateia, Pupo acredita ser mais uma "tentativa de escamotear o autoritarismo do elemento adulto" (p 100-101) onde as explicitações do fenômeno teatral traduzem uma postura professoral. Assim ela afirma:

[...] em ultima análise, é uma tentativa de esvaziamento da própria função simbólica, intrínseca a toda e qualquer linguagem artística. O didatismo simplista acaba triunfando sobre uma visão da arte teatral enquanto possibilidade específica de conhecimento. (PUPO, 1991 p.101).

Pupo se debruça também sobre a composição dos personagens, apontando a precariedade em sua construção, em relação à ausência de contradições internas, predominando a linguagem verbal em detrimento da ação, veiculando generalizações e preconizando abertamente modelos de comportamento servindo "à manutenção de privilégios de ordem social transmitindo assim uma visão de mundo basicamente conformista" (p. 129), uma vez que há ausência de representações como a sexualidade infantil, a cor negra é associada ao mal ou ao estereótipo da docilidade e a mulher ainda bastante veiculada ao ambiente familiar assimilada à dependência e a não produtividade (PUPO, 1991).

Refletindo o teatro infantil hoje, Carlos Augusto Nazareth (2012) com seu olhar aguçado sobre essa expressão artística, nos mostra poucas mudanças comparado ao cenário exposto por Pupo sobre a década de setenta. Ele revela o estabelecimento de um conjunto de procedimentos próprios de um "teatrinho infantil" chamado por ele de estética perversa do teatro infantil. Assim Nazareth afirma:

Essa estética perversa, a inércia do público, a visão apenas mercantilista de alguns, a ausência e negação da crítica especializada, a falta de espaço de discussão, de patrocínios públicos e privados, vão aos poucos transformando o teatro infantil num dragão de sete cabeças, tornando-o um fenômeno, por vezes, incompreensível (NAZARETH, 2012, p. 75).

Pautado nessa estética, Nazareth (2012) discorre sobre diversas camadas da recepção do espetáculo teatral e seus meandros. No que diz respeito ao texto, ele critica o 
excesso de adaptações e a falta de consciência nesta modalidade, alertando: "descobrir o que tem a dizer é a primeira tarefa do dramaturgo" (p. 79), valendo-se também aos textos originais, onde a falta de um conteúdo a ser veiculado "estabelece o primeiro e mais grave preceito dessa estética perversa" (p. 79). Sobre as adaptações ele categoricamente afirma:

As adaptações dos clássicos deixam de lado a essência da história, que as fez atravessar anos, narrativas fundantes, mitos que se tornaram contos populares, transmitidos por meio da tradição oral. Esta essência tem de estar na adaptação. E o que acontece é que os adaptadores normalmente pegam a tênue trama desses contos e se importam apenas com ela, modificando-a, "atualizando-a" de modo absurdo, onde celulares, shoppings, Hebes Camargos e Xuxas geralmente estão presentes. O sumo, o suco, a essência, o mítico é deixado de lado, talvez porque nem saibam da existência desse lado, talvez porque não estudem, não pesquisem aquilo que vão adaptar (NAZARETH, 2012 p. 79).

Tal percalço no cenário do teatro infantil torna turva a visão de uma solução, uma vez que pais, escola e teatros só intensificam esta estética perversa, não motivando a inserção da criança no universo da arte e quando o fazem didatizam as experiências e reduzem as possibilidades de leitura, afastando-as de qualquer expressão artística. Cabe salientar as práticas observadas por Nazareth nas casas de espetáculo:

Os melhores teatros acolhem em sua programação muitos espetáculos construídos dentro da estética perversa Os shoppings são mestres em exibir espetáculos feitos sob a égide da estética Disney, piorada. O que importa é receber o mínimo e não deixar furo em sua pauta, pois os próprios programadores pouco estão interessados em avaliar o que está em cartaz. Um projeto é um enigma difícil de ser decifrado mesmo para os profissionais mais experientes $\mathrm{O}$ que norteia essa decisão normalmente é a qualidade gráfica do projeto. É a estética do projeto que é avaliada, não a estética do espetáculo (NAZARETH p. 77).

Em contrapartida, Marcelo Ramagnoli, dramaturgo e diretor da Banda Mirim, grupo com mais de 10 anos de atuação em artes cênicas para crianças, em seu $\mathrm{O}$ desafio do Teatro para crianças e jovens soma à questão algo importante:

Teatro é um só. Pode ser aqui ou na Ásia, para crianças ou adultos, com ou sem texto. Seu sentido maior não faz diferença entre culturas, idades, gêneros ou classes. Ele acontece quando um diálogo sensível, pensado e ensaiado se estabelece entre palco e plateia. Acontece quando a arte consegue pensar o mundo, o homem e suas relações. E além de pensar, consegue se comunicar efetivamente com a audiência. (ROMAGNOLI, 2014, p.28).

O dramaturgo nos leva à visualização do teatro, sendo arte sensível e expressão humana genuína, como um só. O teatro acontece quando nos propomos a um diálogo sensível que é pensado, planejado, executado para se estabelecer com a plateia, sendo jovens ou adultos. As etapas para o cumprimento deste diálogo devem ser as mesmas, devem seguir os mesmos rigores.

Está claro que os anseios de uma plateia de adultos são diferentes dos de uma plateia de crianças. Os critérios de importância de uma não devem ter juízo de valor sobre a outra. Todo teatro tem seu inegável caráter reflexivo. É preciso acabar com a ideia de que o teatro para crianças é mais fácil. Por isso a necessidade de elencar, nesta criação, as especificidades desse segmento no processo de criação. 


\begin{abstract}
Assim, surge o espaço de se questionar, discutir, e rediscutir a questão do teatro, da arte e sua relação com o mundo hoje, com a criança, com a escola. Discutir, questionar e conseguir dentro dessa democrática pluralidade valorizar o que há de melhor e tentar oferecer isso a esse público que precisa ser tão bem cuidado. Esses seres em formação que necessitam da arte cotidianamente em suas vidas - e não só do teatro - mas de toda forma de expressão artística (NAZARETH, 2012, p.115).
\end{abstract}

As palavras de Nazareth (2012) denunciam para um a necessidade de uma redescoberta do teatro para crianças e jovens, com novas dimensões estéticas, novas politicas públicas, evocando o movimento de diversas esferas para além da classe artística, envolvendo escolas, teatros e tutores. Mesmo o teatro, uma arte milenar, parece que ainda não recebeu a atenção devida da arte na formação humana de um indivíduo e na dimensão política e social contida na arte para crianças.

Escrever sobre processo criativo é antes e acima de tudo uma aventura árdua pelo pensamento, pela memória. Nessas paragens de reflexão pós-vivência não pretendo oferecer um caminho certo a ser seguido ou postular uma fórmula metodológica de como criar uma obra artística, mas parto da experiência como mola de conhecimento que reverbera em outras experiências. Assim, dilucidar o processo criativo dessas dramaturgias observando suas formas, estruturas, narrativas e resultados significa dar voz a meu processo de formação artística, aos caminhos que venho trilhado e passar a ver os que poderei trilhar, aqui está uma escritora se colando pautada na pesquisa em artes, aquela que não vê o conhecimento separado do pesquisador e que objetiva a compreensão da prática artística, possibilitando autonomia na formulação das próprias perguntas e a busca por respostas "através de um processo interativo entre exploração prática de sua artform, seu fazer artístico, e compreensão teórica do que está em questão" (FORTIN; GOSSELIN, p.7, 2014).

Acreditando na força do compartilhar de experiências criativas para este panorama de discussões e compreendendo a importância de abrir espaços para reflexão e questionamentos sobre o teatro para crianças e jovens, que neste escrito me debruço a refletir a escrita do texto dramaturgico de Cecília e os 40 fantasma e Aventura do Lobo, assumindo que o teatro para crianças se consubstancia por meio da práxis. Nestas experiências aqui traçadas sigo a luz de um teatro contemporâneo que está em resposta ao tempo que comparecemos.

\title{
2. Escrevendo o Riso em Cecília e os $\mathbf{4 0}$ fantasmas
}

Minha primeira tentativa escrevendo um texto para a cena, foi à quatro mãos, as minhas e as mãos de Nicolle Machado ${ }^{2}$, livremente inspirado no conto Sabrina e os 40 fantasmas de Gustavo Finkler e Raquel Grabauska por ocasião da disciplina de teatro

\footnotetext{
${ }^{2}$ É Atriz, mestranda em Artes Cênicas pela UFU (2018), especialista em Ensino de Arte e Movimento pelo Centro universitário Cidade Verde, possui Licenciatura em Teatro pela Universidade Federal do Maranhão e Bacharelado em Administração pela Universidade Ceuma. Teve trabalhos artísticos, acadêmicos e eventos nas áreas de Artes Cênicas e Comunicação Social. É integrante do Grupo de Pesquisa Laboratório de Tecnologias Dramáticas /LabTecDrama pela UFMA e do Grupo ASFALTO - texturas entre artes e filosofias pela UFU. Atua artisticamente e academicamente nos eixos de formação artística, processos criativos em artes cênicas, performance, encenação, dramaturgia e pedagogia do teatro.
} 
infanto-juvenil (2013) ministrada pela professora Michelle Cabral ${ }^{3}$. Surge nesta disciplina, cheia de discussões sobre o universo da criança, o texto do espetáculo "Cecília e os 40 fantasmas",

Cecília e os 40 fantasmas é um espetáculo movido pelo circo. Cecília, seu irmão Jaime, e a mãe são como qualquer família, inclusive como a minha. A trama se dá quando esta família de circo sai do picadeiro e Cecília é tomada pelo medo de fantasmas após ver um vídeo na internet mostrado pelo seu irmão mais velho que não perdendo a oportunidade de uma traquinagem, arma um plano para assustá-la vestindo-se de fantasma. Muitas trapalhadas acontecem quando a mãe chega no quarto esbaforida para acalentar sua filhinha medrosa. É nessas confusões que esta família de palhaços compõem um jogo divertido e cheio de surpresas com uma indagação preocupante para muitas crianças: Será que fantasmas existem?

Mesmo que pouco, nosso contato com técnicas de circo através da Professora Michelle foi fundamental para entender nosso espetáculo nesse universo colorido e visualizar um mar de possibilidades prestes a serem exploradas. Tal aproximação é historicamente conhecida, uma vez que "teatrólogos do início do século XX que investiram no rompimento com a cena realista não escaparam ao encanto do circo" (BOLOGNESE, 2006, p.9), nos rendemos também a esse encanto, e suas possibilidades teatrais.

Embora a escrita de "Cecília e os 40 fantasmas" para a disciplina fosse uma escrita instintiva, em que pouco sabíamos sobre dramaturgia, ao sairmos da disciplina para nos lançarmos numa remontagem do espetáculo, assumimos uma escrita híbrida assemelhada a ideia de roteiro, onde o texto foi se moldando à medida que os atores foram descobrindo seus palhaços, numa composição que podemos chamar de dramaturgia aberta, isto é, não acabada e submetidas a constantes mudanças tal como no próprio circo em que "o público participa ativamente do desempenho do palhaço, inclusive direcionando, no ato de improvisar, a expansão ou o retraimento das entradas e reprises" (BOLOGNESE, 2003 p.198)

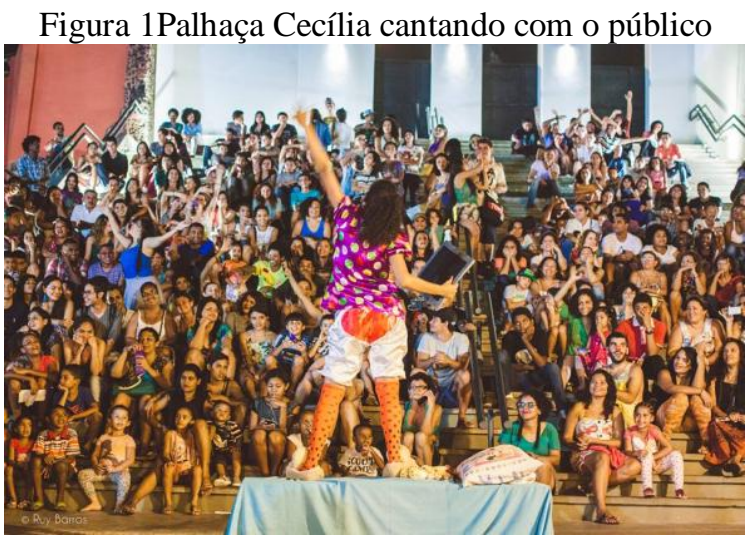

Fonte (Ruy Barros, 2015)

\footnotetext{
${ }^{3}$ Profa. Dr. Michelle Cabral é doutora em Comunicação Social (PUC/RS), professora adjunta do curso de Licenciatura em Teatro do Departamento de Artes da Universidade Federal do Maranhão - UFMA. Tem experiência na área de Artes Cênicas, com ênfase em Teatro, atuando principalmente nos seguintes temas: poéticas do teatro, encenação, performatividade, circo e história. Atualmente pesquisa sobre Performatividade e Espaço Público: Processos comunicacionais no teatro de rua. (fonte: site do curso de teatro/UFMA Disponível

em: $\langle$ http://www.teatro.ufma.br/index.php?option=com content\&view=article\&id=13\&Itemid=143) $>$.
} 
O Palhaço, como "ponto de estreita ligação entre o circo e o teatro" (BOLOGNESE, 2003, p.194) tornou-se nosso principal desafio. Longe de serem dominados por um texto prévio, percebemos sua autonomia e altivez, o texto alterava-se a cada ensaio à medida que os atores assumiam seus palhaços, apoiados em sua própria subjetividade.

É preciso falar da descoberta. Cecília e os 40 fantasmas era um espetáculo de palhaços. Não um palhaço alegórico, um palhaço infantil. O nosso palhaço não era para crianças, mas sua pureza e ridicularidade deveria alcançá-las, aos adultos deveríamos o arrebatamento do cotidiano. O trabalho era de aceitação, de uso do fracasso. Nossos palhaços precisavam do erro e precisavam mostrá-los, festejálos. Mas quem quer se sentir fracassado? Não eram personagens, eram os ridículos de cada um. Alguns desabrocharam e extravasaram o que tinham sem a pretensão do riso, e por isso mesmo tanto nos fizeram rir. Outros se esconderam na cena e tanto nos fizeram bocejar. Mas um processo sem volta aos que foram atravessados. O palhaço, nosso maior algoz e nossa salvação. (Trecho do Portfólio de Prática de Extensão I escrito por Nicolle Machado, Renato Guterres e Luciano Ferrgar).

Costumamos ver o circo como um lugar de sonho, cores e magia com cheiro de algodão doce, onde podemos nos surpreender tal como eu quando criança ao ver o número do globo da morte e a noite não conseguia dormir de tão impressionada, ou mesmo um lugar de encantamento presente no olhar das crianças ao verem as cores do circo. Quando me vi no circo, não tínhamos lona, éramos alguns poucos aprendendo malabares numa praça com uma perna de pau emprestada, mas se na história do circo os laços entre os circenses eram de família, nós tínhamos isso no Coletivo O Circo tá na Rua ${ }^{4}$

Em contato com esse projeto social e que hoje firmou-se como coletivo artístico, me descobri malabarista, equilibrista, gente de circo. No projeto pouco se tem a relação professor aluno como se costuma ter em ambiente escolar, a troca de experiências é o de mais valioso, não se vê a costura do ensinar e aprender como uma relação hierárquica, e os encontros para treinar circo acabaram virando encontros culturais reconhecidos na cidade.

Este conviver com o circo foi fundamental para a compreensão de muitos aspectos contidos no espetáculo Cecília e os 40 fantasmas, a linguagem do circo aparentemente um mero acessório de conceito estético do trabalho, na verdade era um fio que alinhavava desde o processo através do palhaço para treinamento do ator, até o uso de malabares, perna de pau e narizes.

A remontagem de Cecília no ano de 2015 gerou um coletivo universitário que buscava experimentar a cena. Nossos anseios culminaram em uma identidade mesclada por linguagens artísticas variadas inseridas em textos próprios: o Coletivo Cênico Respeite Minha cidade 5 .

\footnotetext{
${ }^{4}$ O Coletivo O Circo tá na rua surgiu em 2013, coordenado por Donny dos Santos, professor artista e fisioterapeuta, desenvolvendo treinos semanais gratuito de diversas modalidades de circo na Praça Nauro Machado, em São Luís/MA, além de espetáculos e intervenções com a mesma linguagem. Dentre os trabalhos do Grupo destacam-se a intervenção Voadores, Fogo de Prometeu e o espetáculo Héstias.

${ }^{5}$ O Coletivo Cênico Respeite A Minha Cidade! surgiu em 2013, pela iniciativa de um grupo de alunos do curso de Teatro Licenciatura da Universidade Federal do Maranhão. Em 2014, selecionado para o Encontro Nacional de Estudantes (Viçosa-MG), estreia o espetáculo "Pacto Carmim", com direção de Luciano Teixeira, também apresentado no II Festival Ponto de Vista.
} 
Olhando atentamente a dramaturgia construída, há uma relação com o representar do improviso, isto é, "elementos prévios que dão contorno ao jogo cênico" (BOLOGNESE, 2003, p. 196). Tal como no circo, o texto de "Cecília e os 40 fantasmas" é escrito por um roteiro de entradas, "que demarca um certo número de situações cômicas, quer seja na fala propriamente dita, quer seja na ação corporal” (BOLOGNESE, 2003, p.196). Dessa forma, o esquema dramático pauta-se pelos seguintes elementos: palhaços personagens; entradas; e a interação com o público, este último de importância equivalente aos demais.

JAIME - Ah! Sua medrosa! É por isso que aqui no teu quarto moram 40 fantasmas!

CECÍLIA - Mentira, que eu já sou grande e sei que fantasmas não existem! ${ }^{6}$

O desenrolar das ações depende da adoção de uma dramaturgia aberta, na qual Cecília ao explorar sua relação com todos na plateia sobre quem tem medo de fantasmas, quem acredita em sua existência, ao passo que Jaime ao contrapor a coragem da irmã e também dos expectadores, criam um jogo único com público (estes trazidos para a trama desde o início do espetáculo através dos números apresentados numa relação harmoniosa ao que Bolognesi (2003) chama de correspondência entre o interior (o público) e o exterior (o espetáculo) dividindo-os entre corajosos e medrosos. Neste caso, o tempo da improvisação é determinante, ele dita o momento de finalizar este jogo coragem versus medo e inicia um novo com a entrada da palhaça mãe que os pega de surpresa na hora em que usam um tablet e brigam quando deveriam estar dormindo.

Figura 2: Entrada da palhaça mãe

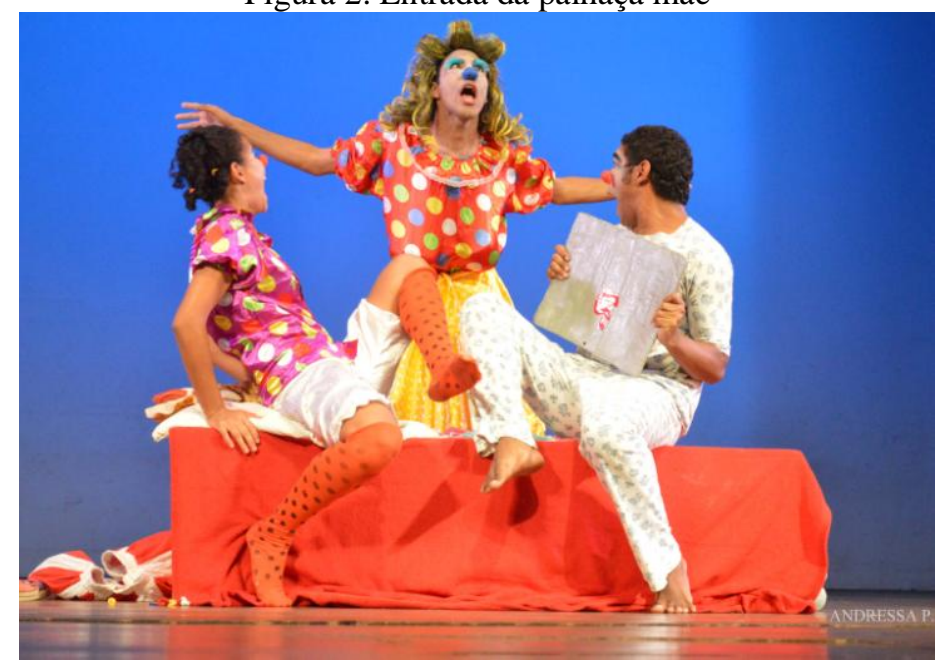

Fonte: (Andressa Passos, 2015).

É dessa maneira que o tempo de brincar e improvisar é domado pelo público que "intervém no espetáculo e na performance dos palhaços. A improvisação é a insólita ferramenta do palhaço e nesta, o acaso e o inesperado exercem uma influência decisiva" (BOLOGNESE, 2003, p. 198). É dessa comunicação/jogo entre Cecília, Jaime, mãe e público que resulta a encenação, assim nos explica Bolognesi.

\footnotetext{
${ }^{6}$ Trecho da dramaturgia de Cecília e os 40 fantasmas
} 
[...] os passos da realização cênica não estão de todo previstos por uma encenação previamente preparada, e ao mesmo tempo controlado pelo esquema proposto pelas entradas ou pelas reações do público. Em cena, a eficácia da interpretação opera com o comunicar-se com um outro palhaço, com o apresentador (ou com ambos) e com o público, que passa a ser uma personagem do jogo cênico improvisado. (BOLOGNESI, 2003, p.197)

Cecília muito me lembra de uma menina que gostava de subir em árvores, ler livros de fantasia, brincar com seus amigos pelo bairro e que sempre era a mais protegida pela mãe, e pela vó. Jaime diria exatamente isso de Cecilia, aliás, Jaime me lembra do irmão dessa mesma menina, sempre se metendo em confusão e deixando sua irmã apavorada com suas histórias de terror.

Sinisterra (2016) afirma que escrevemos a partir de uma teatralidade inscrita em nossa experiência e devo confessar que muito do que escrevi para este espetáculo veio da minha infância: das disputas com meu irmão mais velho seja na esperteza de quem chegava primeiro para não ser a mulher do padre, quem não tinha medo do escuro ou ficava mais tempo sem piscar os olhos.

Cecília e Jaime tinham empasses não muito diferentes, disputavam o tablet ou quem assistia a mais vídeos no You tube, (essas crianças/palhaços (as) de hoje...), mas também disputam a coragem na noite escura, a esperteza e a atenção da mãe, tal como os palhaços tradicionais que disputavam o amor, o saber ou o dinheiro numa relação de dominado e dominador, dicotomia que permitiu ao circo dar ao público não só boas risadas, mas também um exercício ao raciocínio, onde o sublime e o grotesco se interpenetram, tecem uma dimensão política.

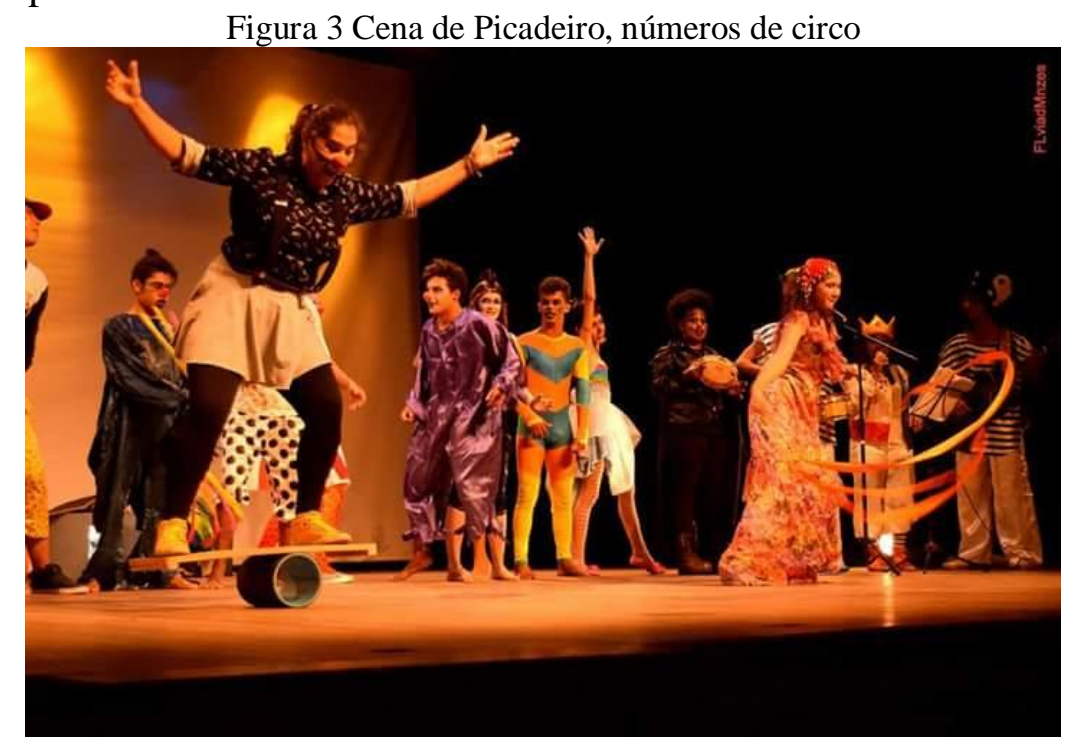

Fonte: (Flávia de Menezes, 2014).

O espetáculo apoia-se nesse jogo de dar e tomar em toda sua dramaturgia, com os olhos abertos ao risco, a manutenção das sensações do circo e ao corpo disforme do palhaço, na medida em que explorávamos nossos limites e assumíamos nossa identidade em construção, ainda experimental. 
Escrever um roteiro dramatúrgico em dupla, foi uma aventura repleta de significados e aprendizados, uma vez que ambas estávamos descobrindo nosso escrever teatral, apesar de "Cecília e os 40 fantasmas" surgir da manobra de dramatizar um conto, demos liberdade a nossa imaginação e criamos uma estória própria a partir dos palhaços. Permitimo-nos errar e ver o espetáculo nos palcos da cidade ${ }^{7}$ nos deu o paradoxo que todo criador vive, quando a subjetividade e a alteridade "se entrelaçam em processos tanto mais ricos quanto mais se assume, justamente, a alteridade da escrita". (SINISTERRA, 2016, p.14).

\section{Aventura do Lobo, dramaturgismo e performatividade.}

Aventura do Lobo surgiu também em experimentações na universidade ${ }^{8}$, dessa vez numa relação de escrita e direção quase que indissociáveis e urdidas em sala de ensaio. O espetáculo narra a saga de Raul, um lobo rockeiro da floresta que tem uma fome de coelho urbano, e que por isso vai para cidade em busca de seu almoço e se depara com um condomínio de bichos urbanos, sempre que Raul apresenta um objeto que servirá a captura do coelho, surge um morador o pedindo emprestado

Aqui estabelo uma tentativa de resumo ${ }^{9}$ de um importante aspecto comtido na dramaturgia de Aventura do Lobo, sua performatividade, nela o texto construído a partir de seus atores suscitam uma dramaturgia imbricada na encenação forjada na sala de ensaio. No processo que citei anteriormente, o texto modificava-se a partir da construção dos palhaços, seguindo seus jogos de cena e seus tipos cômicos, aqui percegue-se corpo, subjetividade e narrativas do ator para costrução dos personagens e falas do texto.

Através de proposições em sala de ensaio, materialidades dos atores e atrizes foram servindo ao texto, a dramaturgia era guiada e inscrita na atuação, evocando um texto feito a partir de quem estivesse em cena, seja suas habilidades artísticas, gestos, características, histórias ou lembranças dos atores e atrizes.

Por exemplo, o personagem Coelho, interpretado por Alysson Ericeira, era malabarista e contador de histórias, essas eram habilidades artísticas do ator. Alysson também gostava de rock, seus vícios, gestos e especificidades como modo de andar, abrir

\footnotetext{
${ }^{7}$ O Espetáculo "Cecília e os 40 fantasmas" com três anos de existência já apresentou em diversos eventos da cidade, além das duas apresentações de estreia e também da apresentação do projeto de extensão I, esteve em cartaz no Teatro Alcione Nazaré, no aniversário de 2 anos do Projeto O circo tá na rua, foi selecionado para a X Semana do teatro no Maranhão e também para $10^{a}$ Feira do Livro de São Luís além de participar de eventos como $14^{a}$ Semana de Museus, realizada pela ONG Nave e Museu Histórico e Artístico do Maranhão na comunidade do Cajueiro, Oi Jogos de Verão, evento do estado e outros.

${ }^{8}$ Espetáculo foi montado na disciplina Prática de Encenação em 2015, ministrada pela Profa. Ma. Ana Teresa Desterro Rabelo (UFMA) e contou com os discentes Alysson Ericeira Sousa, Arison Robert Campos Nascimento, Arlinda Souza Menezes, Carla Souza Purcina, Epaminondas Sidra Diniz, Isamara Fernanda Martins de Oliveira, Necylia Maria da Silva Monteiro e Tiago Pinheiro Andrade. Após a estreia para a disciplina a produção do espetáculo foi assumida pela Cia Artífice-mor em parceria com o Grupo Cena Aberta, sendo apresentado em muitos festivais de teatro como a Semana de Teatro no Maranhão (Teatro Arthur Azevedo) e Semana da Criança (SESC-MA).

${ }^{9}$ A trajetória de criação dramatúrgica desse espetáculo foi sistematizada e explicitada por etapas através da Genética teatral em meu trabalho monográfico de graduação AVENTURA DO LOBO: Uma narrativa de Criação em Dramaturgia defendido em 2017 na Universidade Federal do Maranhão sob orientação da Prof. Dra. Fernanda Areias de Oliveira.
} 
bem os olhos e falar, suas gírias e expressões, ou seja, características pessoais do ator que foram incluídas ao material de elaboração do personagem.

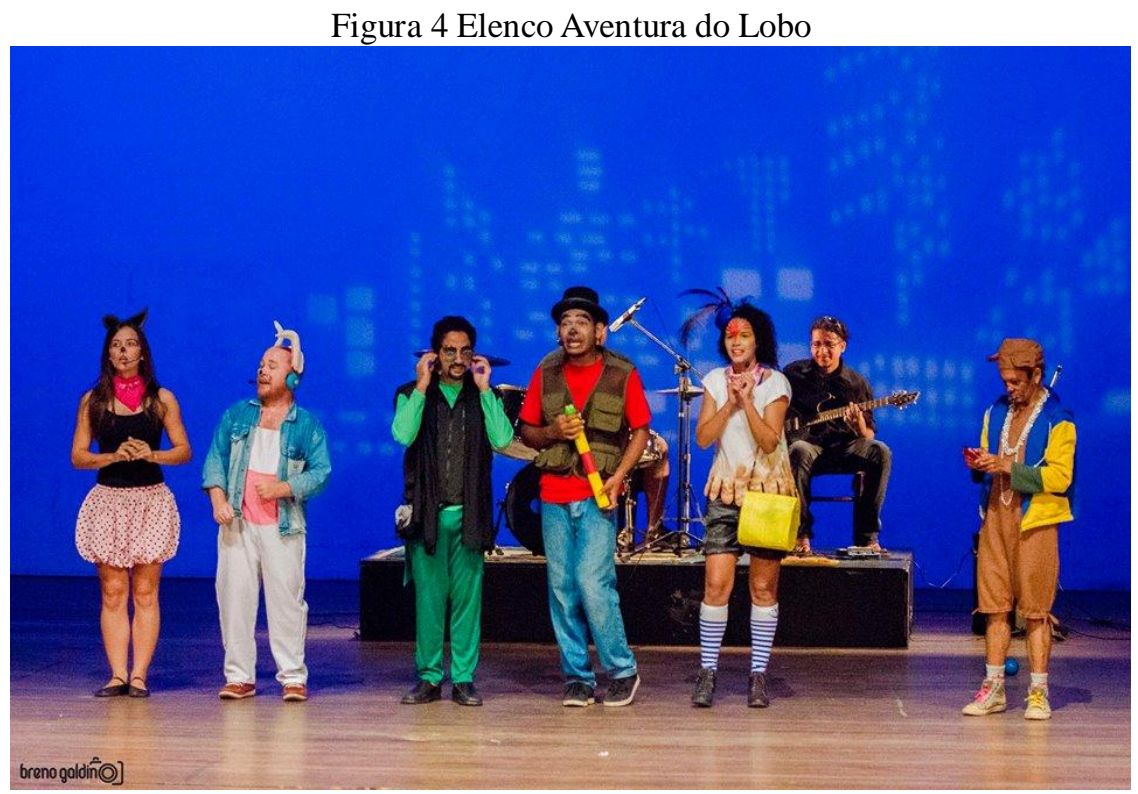

Fonte: (Breno Galdino, 2016)

Somado às características pessoais e habilidades artísticas, em todo processo de sala de ensaio trabalhávamos as memórias dos integrantes de suas idas à zona rural ou mesmo de suas cidades natais no interior do Maranhão. Essa relação ajudava a pensar o jogo cidade e floresta, contido na narrativa da peça.

Dessa forma, a construção do personagem se distancia do ator, de sua pessoa cotidiana, somente pelo exagero e comicidade inseridos numa ideia de performatividade de si. $\mathrm{O}$ andar do ator, seus gestos, suas expressões, tudo era aumentado ou diminuído à escolha do processo pensando na inserção desse material no contexto fabular.

Percebo nesse processo de construção dos personagens, em que os atores emprestam sua personalidade sugerindo tipos e formas a eles, semelhante à busca do palhaço em que a construção do personagem por assim dizer "obedece a um determinado perfil individual, que se apoia nas características corporais do ator e em sua própria subjetividade" (BOLOGNESI, 2003. p.198).

Nesses tipos cômicos há uma experimentação da liberdade, longe das formas rígidas do cotidiano, onde o risível nos aproxima de sensações da infância, o palhaço quando cômico se apoia no exagero de seus vícios e em sua possibilidades artísticas, é dessa relação pauta-se o exercício de criatividade em "Aventura do Lobo".

Logo no início desta caminhada criativa onde foram traçadas as identidades dos personagens, era um objetivo sua construção para além de personas no palco cênico, para além das cenas, uma vez que os animais estavam tão imbricados na personalidade dos atores vi a possibilidade de provocar um estado de presença desses animais, um estado performativo que possibilitasse sua atuação em qualquer ambiente ou situação.

Tal ideia foi difundida através de processos criativos nos ensaios ao que chamei de Cenas de situação em que os personagens eram incluídos em situações diversas, fora do 
ambiente da narrativa do espetáculo, porém não contraditório a ele. Abaixo alguns exemplos:

Quadro 1: Cenas de situação

\begin{tabular}{|l|}
\multicolumn{1}{c|}{ CENAS DE SITUAÇÃO } \\
\hline Situação 1 O grilo inspeciona pacotes da portaria \\
\hline Situação 2 O urso ensina uma coreografia para os moradores \\
\hline Situação 3 A Perua foi convidada para um programa de culinária \\
\hline Situação 4 A Loba dá uma aula de balé para o Lobo e Coelho \\
\hline
\end{tabular}

(Fonte: arquivos da autora)

A eficácia de procedimentos como esses que despertavam ao estado performativo pode ser atestada em situações diversas em que se percebe o estado do personagem fora do palco como, por exemplo, em uma entrevista para a TV ou mesmo participando de um programa de estúdio onde os atores interagiam com o repórter ou apresentadora como personagens animais evocando a uma abordagem de intervenção no espaço conforme destaca Féral (2015):

A performance se propõe, com efeito, como modo de intervenção e de ação sobre o real, um real que ela procura desconstruir por intermédio da obra de arte que ela produz. Por isso ela vai trabalhar em um duplo nível, procurando, de um lado, reproduzi-lo em função da subjetividade do performer; e, de outro, desconstruílo, seja por meio do corpo - performance teatral - seja da imagem - imagem do real $[\ldots]$ (p.137).

Certamente a partir dessas experimentações deu-se a criação da cena final do espetáculo, de caráter performativo esta se constitui como um roteiro descritivo dos acontecimentos da ação cênica, o concurso de talentos privilegia o conflito entre os personagens e seu desfecho de maneira orgânica, é um roteiro aberto suscetível a imprevistos e mudanças onde cada ator e atriz decide qual número irá apresentar. Do mesmo modo o roteiro da cena final abre possibilidades a mudanças na trama como é o caso da cena de votação do concurso de talentos em que cabe a plateia eleger o vencedor, essa relação de roteiro como descrição dos eventos, característica fundamental da performatividade pode ser observada a seguir:

CENA 11 - Todos se colocam em fila de frente para a plateia, o Lobo se coloca como integrante do concurso, se apresentam todos os personagens em ordem definida previamente ou não, suas apresentações dependem dos talentos que os atores desejam exibir, cabe aos atores decidir sobre a inclusão do público no concurso. Quando chega a hora do lobo se apresentar, este é pego de surpresa, mas aceita mostrar seu talento, ele pega o microfone e canta, de imediato o coelho percebe ser seu ídolo, ao final da música... (Trecho de "Aventura do Lobo", arquivo pessoal). 
A utilização dessa relação performance e teatro é como afirma Féral (2008) fruto de uma desconfiança recíproca e que em "Aventura do Lobo" é utilizada na busca por uma Performatividade Cênica em que o teatro se beneficia das aquisições da Performance constituindo-se para Josette Féral, Teatro Performativo, assim ela diz:

[...] se há uma arte que se beneficiou das aquisições da performance, é certamente o teatro, dado que ele adotou alguns dos elementos fundadores que abalaram o gênero transformação do ator em performer, descrição dos acontecimentos da ação cênica em detrimento da representação ou de um jogo de ilusão, espetáculo centrado na imagem e na ação e não mais sobre o texto, apelo à uma receptividade do espectador de natureza essencialmente especular ou aos modos das percepções próprias da tecnologia [...] (FERAL, 2008 p.198)

Não cabendo o retorno histórico da conceituação da performance admite-se aqui seu sentido dominante apresentado por Schechner no que diz respeito ao performer considerando sua explícita importância uma vez que segundo Féral (2008) esta redefiniu os parâmetros permitindo-nos pensar a arte hoje, sendo evidente também que a prática da performance teve uma incidência radical sobre a prática teatral como um todo. Schechner nos destaca as três operações para pensar a prática de um performer:

1. ser/estar ("being"), ou seja, se comportar ("to behave"); 2. fazer ("doing"). É a atividade de tudo o que existe, dos quarks aos seres humanos; 3. mostrar o que faz ("showing doing", ligado à natureza dos comportamentos humanos). Este consiste em dar-se em espetáculo, em mostrar (ou se mostrar). (FERAL, 2008 p.200)

Nestas operações é possível identificar principalmente a construção do estado de presença do Lobo Raul, seu corpo expandido sempre em cena, seja em interações no camarim, no palco ou em interação com as crianças após o fechamento das cortinas, ideia contrária a manutenção de iludir a criança a acreditar na veracidade de sua existência a performance do ator privilegia a ação, seu aqui e agora, o dar-se em espetáculo, "it happens", disse Schechner, onde seu fazer se torna primordial.

A narrativa incita a uma viagem no imaginário que o canto e a dança amplificam. Os arabescos do ator, a elasticidade de seu corpo, a sinuosidade das formas que solicitam o olhar do espectador em primeiro plano, estão no domínio do desempenho. $\mathrm{O}$ espectador, longe de buscar um sentido para a imagem, deixa-se levar por esta performatividade em ação. Ele performa. (FERAL, 2008 p.202)

Dissipando a ilusão e instaurando um estado de presença sua relação com o jogo da representação torna-o comandante do espetáculo que na maioria das vezes não se atém a meras falas gravadas e propõe-se ao risco, onde nota-se o engajamento do artista em que suas subjetividades alargam-se, característica também pertencente ao circo em sua relação com o sublime do riso e o público. O performer não se atém a improvisar rimas que não estão no texto escrito, ou falar diretamente com o ator que esqueceu-se de uma ação, é possível ele traçar novas relações, jogos e deixar-se livre para agir, para fazer, como afirma 
Féral (2008) "o teatro performativo toca na subjetividade do performer", portanto concluise:

No teatro performativo, o ator é chamado a "fazer" (doing), a "estar presente", a assumir os riscos e a mostrar o fazer (showing the doing), em outras palavras, a afirmar a performatividade do processo. A atenção do espectador se coloca na execução do gesto, na criação da forma, na dissolução dos signos e em sua reconstrução permanente. Uma estética da presença se instaura (se met en place) (FÉRAL, 2008, P 209)

Assim, o conceito de Teatro Performativo proposto por Josette Féral surge do cruzamento emergente dos dois eixos principais de discursão da performance (performance como arte e performance como experiencia, competência) de onde incide a diversidade do teatro atual, ao que Hans-Thies Lehmann chamou de Teatro pós dramático.

Em conformidade à ideia de Teatro performativo em "Aventura do Lobo" e resgatando a questão ao qual esta pesquisa se propõe no que tange investigar a identidade do texto sob olhar de seu processo criativo indissociável de sua representação cênica, sublinha-se aqui a conceituação de Texto Performativo também proposta por Josette Féral (2015) que se origina na interrogação sob um espetáculo que se forja a partir da prática.

\section{Traçando uma identidade na escrita}

Os processos de escrita aqui apresentados e outros tantas experiências em que escrever um texto estava dissociada a prática da sala de ensaio e aos sujeitos que compõe a criação me levou a perceber meu lugar e identidade na escrita de textos para o teatro. Esta escrita, tida num conceito amplo de Dramaturgia, é como ação que contém as principais discussões estéticas e políticas sobre o que dizer, quem diz e como dizer, reflexiona Marcio de Abreu (2010) em artigo para a revista Subtexto. Frente a um terreno estriado de procedimentos de criação que respondem às urgências do nosso tempo intempestivo, nesta pesquisa essa escrita é ponto crucial, acompanhada dos seus modos de feitura, sua tecelagem.

Carlos Augusto Nazareth (2012), em seu olhar do espetáculo teatral como uma tessitura, afirma que podemos tomar um texto como expressão do universo, sendo o macrotexto, o universo composto de milhões de microtextos que interligados o estruturam e onde os textos de arte refletiriam por mimetismo os textos da vida.

Tecido, urdidura, trama: o espetáculo é um tecido composto da urdidura e da trama de diversas linguagens: o texto, o ator - seu corpo, sua voz, sua interpretação - a música, a luz. Ele traz ideias e emoções tem música, plasticidade, movimento, corporalidade. (NAZARETH, 2012, p.26)

Nesse aspecto, tratando da função do autor de peças de teatro levanto a percepção do dramaturgo como um fiandeiro, aquele que organiza os fios num tear. Esses fios pode-se dizer, são as materialidades escritas, as ideias, os argumentos, as colagens e o tecido feito é o texto final, não excluindo essa relação de alteridade frente aos outros profissionais do processo. Pelo contrário, esse jogo é matéria importante.

Nessa perspectiva, pensar em dramaturgia contemporânea é atestar sua pluralidade em formas híbridas e longe de generalizações. Em Notas sobre a Dramaturgia contemporânea, Fernandes afirma: 
A diversidade da produção chega a ponto de levar um pesquisador da envergadura de Patrice Pavis a definir o texto teatral pelo critério elocutório. Segundo o teórico francês atualmente texto de teatro é tudo aquilo que se fala em cena. O que parece um exagero de simplificação encontra eco no encenador americano Richard Schechner para quem drama é tudo o que o escritor escreve para a cena e se opõe a script, o roteiro que serve como mapa de uma determinada produção (FERNANDES 2010, p.153).

A autora nos alerta sobre a observação de que "uma das principais tarefas do estudioso do texto teatral contemporâneo seja distinguir seu objeto". É neste cenário, onde o texto desafia qualquer padronização ou corrente, que busco uma identidade na escrita para o teatro em sentido dialógico com a sua prática.

Em vista disso, atenho-me aos estudos de Fátima Saadi ${ }^{10}$ que tratam da função de dramaturg ou dramaturgista, termo que etimologicamente significa poeta da cena. Sua função varia conforme as demandas da criação e relação com a equipe, suas atividades em longo prazo mostram possibilidades de aspecto multidisciplinar e transitório uma vez que "afirma-se que um dramaturg acaba sempre por encontrar seu próprio destino vindo a realizar-se como diretor, autor dramático ou crítico teatral”. Sobre suas diversas funções, a dramaturgista diz:

As tarefas do dramaturgista são múltiplas. Entre elas, eu listaria: colaborar no delineamento do projeto artístico do grupo e na sua difusão; participar da escolha do repertório; ler e comentar peças que sejam enviadas para apreciação; traduzir, criar ou adaptar textos ou materiais que sirvam de base para o espetáculo; trabalhar, juntamente com o encenador, na criação do conceito dos espetáculos, oferecer o material de pesquisa necessário à montagem; acompanhar os ensaios para comentar o desdobramento cênico da proposta durante sua concretização; elaborar o programa do espetáculo e demais publicações do grupo; organizar debates com o público; realizar o registro das atividades da trupe. (SAADI, 2013)

Os estudos da dramaturgista Fátima Saadi e seu compartilhar de experiências me leva a ver a posição de um(a) autor(a) em movimento, não obrigando mais a dramaturgia a esse papel de um escrever solitário, resultando numa implosão que libera a coletividade do fazer teatral, onde o dramaturgista atua em contato estreito e contínuo com demais profissionais e com a construção da cena. Ele está nessa articulação dos elementos que compõe o espetáculo teatral, na polifonia de significantes, na tensão entre o pensamento e a forma.

Do mesmo modo, Adélia Nicolle ${ }^{11}$ (2005) se debruçou a entender tal função inserida no grupo interessando-se por particularidades do dramaturgismo. Ela elenca: "confeccionar, organizar, estruturar o roteiro ou texto, além de amparar os estudos teóricos necessários à montagem - sempre vinculada ao trabalho do encenador” (p.27). A autora

\footnotetext{
${ }^{10}$ Fátima Saadi é tradutora e dramaturgista da companhia carioca Teatro do Pequeno Gesto, no âmbito da qual edita a revista Folhetim e a coleção Folhetim/Ensaios.(fonte Revista Questão de crítica disponível em < http://www.questaodecritica.com.br/author/ftima-saadi/>.

${ }^{11}$ Doutora em Pedagogia do Teatro pela ECA- USP (2013) Como dramaturga, escreveu, encenou e publicou diversos textos, além de prestar consultoria a autores e grupos. Como pesquisadora e escritora, publicou artigos, biografias e uma coletânea de dramaturgia. No Magistério há mais de três décadas, já lecionou para todos os níveis.
} 
traz para avultar seu pensamento as experiências de Cacá Brandão ${ }^{12}$ com o Grupo Galpão no início da década de noventa, na montagem de Romeu e Julieta.

Neste espetáculo, o dramaturgista atuou incialmente conduzindo a equipe em estudos específicos para encenação e acompanhando os ensaios fazendo diários da montagem. Depois foi solicitado a reduzir o texto em $50 \%$, criar prólogos, cenas e poemas para o novo personagem surgido ao longo do processo, também escrever textos do programa da peça, até que chegou a "intervir no sentido de apurar o texto dito pelos atores e indicar os trechos que melhor funcionavam junto ao público durante os ensaios abertos, reformulando toda a dramaturgia”. Brandão se via o tempo todo como alguém a viabilizar as ideias do diretor, afirma a pesquisadora.

Em Cecília e os 40 fantasmas vê-se uma autoria em movimento sempre ligada a um roteiro e em função de atualizar o espetáculo, costurá-lo a medida dos participantes, em Aventura do Lobo essa relação em fluxo com o a escrita do texto complexificou-se, onde a função do dramaturgismo na sala de ensaio nesta experiência era propor exercícios aos atores e coletar materiais desse grupo, saber suas habilidades e características, perceber o que cada corpo oferecia à construção do personagem em cena e somá-lo ao texto e à encenação por sua vez. Editando, criando e recortando à medida da sala de ensaio e à serviço de um trabalho de direção que pensava movimentação dos atores e todas as especificidades da encenação.

Pensando nessa interseção entre encenador e dramaturgista, o pesquisador José Fausto Soares Rocha Moreira (2016), em entrevista a alguns dramaturgistas encenadores, cita Carla Romero, para quem o trabalho de dramaturgismo "enxerga a possibilidade de criar obras em que pode pensar, conceber e construir um mundo imaginário completo a partir do seu olhar” (p.92). A dramaturgista constrói uma metáfora sobre a função do encenador dramaturgista com a função das mitocôndrias, o primeiro é uma espécie de líder que "participa de todo o processo como transmissores de energia". Analogamente, as mitocôndrias têm por função a crucial tarefa de "realizar o importante processo de respiração celular” (MOREIRA, 2016. p.92). Assim:

[...] o condutor de um processo teatral, ao assumir os dois papéis, precisa aproveitar cada componente, pois, através de profissionais envolvidos e aplicados ao máximo para a construção do espetáculo, é possível criar uma obra conjunta a partir da orientação de um líder. Portanto, Carla Romero, desde o momento em que passou a trabalhar como encenadora dramaturgista, viu a possibilidade de articular de maneira mais eficiente as dinâmicas entre os atores, técnicos, espectadores e demais envolvidos. Por isso, para ela, a palavra que melhor define esse profissional é: articulador. (MOREIRA, 2016, p.92-93).

Ainda em suas entrevistas, Moreira (2016) cita o dramaturgista João Falcão, cujo pensamento incide na possibilidade de "realizar a principal função do encenador dramaturgista: captar o máximo de cada envolvido no espetáculo, em especial, do elenco", principalmente quando o texto é de sua autoria. Caso similar ao de Aventura do Lobo, que privilegia os sujeitos envolvidos, sobretudo a atuação também com texto autoral. Ainda segundo Moreira em entrevista ao dramaturgista Falcão:

\footnotetext{
${ }^{12}$ Carlos Antônio Leite Brandão arquiteto e professor, dramaturgista nas encenações Romeu e Julieta (1992) em seguida Um Moliére Imaginário, Partido e Inspetor I do Grupo Galpão/MG.
} 
Ao dominar as etapas do processo, pode tirar de cada membro o que deseja para a obra. Assim, como um "fazedor de espetáculo", não há nada sem a sua participação, ele constrói tijolo por tijolo. Acumular os dois cargos traz a possibilidade de experimentar a cada dia, a cada etapa do trabalho e se os papéis fossem divididos como nas cartilhas, suas funções seriam limitadas, pois "não poderia ser tão mutante e isso não seria completo" (p. 148). (MOREIRA, 2016, p.93).

Levanto essa relação de mutabilidade e completude proporcionada pelo acumulo de funções, citada por Falcão em entrevista, para relacionar o Aventura do Lobo com e situações adversas do processo, que exigem um trabalho ágil sobre a obra. Se esse texto é construído nos moldes de seus atores e conectado à encenação, o que acontece quando há substituição de atores? Na experiência de escrita em Aventura do Lobo, o texto transformase a partir da subjetividade dos novos atores, comprovando a não autonomia do texto perante a encenação. Os novos atores foram inseridos no processo, em que não há imposição do texto já existente, para gravarem e improvisarem, para inscreverem através do processo sua subjetividade.

Dessa maneira, o trabalho de dramaturgismo aliado ao da encenação potencializou a fluência dessa operação, onde foram tomadas estratégias e ações de modo a contornar os percalços. Os atores para substituição, por exemplo, já eram conhecidos pelo grupo, escolha feita para acelerar interação entre atores e reconhecimento de habilidades artísticas. Os motes da narrativa e do personagem foram seguidos enquanto que falas, composição e até cenas do roteiro tiveram que modificarem-se à medida que os novos atores sugeriam novas matérias.

Em Aventura do Lobo a relação com o trabalho de dramaturgismo se deu também na feitura de diários de escrita do texto, elaboração de projeto cultural do espetáculo, escrita de texto do programa da peça, comunicação com equipe de marketing na elaboração de ideias para divulgação, roteiro de vídeos teaser, identidade visual da peça e até pensamento teórico da mesma. Percebemos que as atividades podem ser múltiplas.

Por fim, a exposiçao e breves reflexões apresentadas é uma tentativa de através de procedimentos práticos se estaelecer diálogos sobre a escrita dramaturgica para a infancia, os processos aqui compartilhados se constituem como uma mostra de teatro contemporâneo para crianças onde seu fazer e seu pensar caminham juntos a qualquer outra vertente do teatro, seu percurso é árduo e possui os mesmos parâmetros de qualquer outro tipo de obra teatral feita por artistas engajados com seu trabalho.

\section{Referências}

BARON, Sandra C. Brincar: espaço de potência entre o viver, o dizer e o aprender. In GARCIA, Regina Leite (Org.). Crianças essas conhecidas tão desconhecidas. Rio de Janeiro: DP\&A 2002. p. 53-79.

BERGSON, Henri. O riso: ensaio sobre a significação do cômico. São Pulo: Martins Fontes 2004.

BOLOGNESI, Mario Fernando. Circo e teatro: aproximações e conflitos. São Paulo: Revista Sala Preta USP, v. 6, p. 9-15, 2006. Disponível em: <http://dx.doi.org/10.11606/issn.2238-3867.v6i0p9-19>. Acesso em: 15 out. 2016 
. Palhaços. São Paulo: Editora UNESP, 2003 p.185-201.

BONDIA, Jorge Larrosa. Notas sobre a experiência e o saber de experiência. Rev. Bras. Educ., n.19, p.20-28, 2002, ISSN 1413-2478. Disponível em: <http://dx.doi.org/10.1590/S1413-24782002000100003>. Acesso em: 15 out. 2016.

BORGES, Luciene (coord.). Os desafios da dramaturgia contemporânea brasileira: formação, criação e processo colaborativo. Belo Horizonte: Sub Texto Revista de Teatro do Galpão Cine Horto Ano VII Dez Número 07. 2010.

FERAL, Josette. Além dos limites: teoria e prática do teatro. Tradução J. Guinsburg. São Paulo: Perspectiva, 2015. p. 135-267.

FERNANDES, Sílvia. Teatralidades contemporâneas. São Paulo: Perspectiva: FAPESP, 2010. p. 153-169

LEÃO, Raimundo Matos. Teatro para crianças: dramaturgia e encenação. Revista Repertório: Teatro \& Dança, ano 13, n. 14, p 85-96, 2010. Disponível em: 〈https://portalseer.ufba.br/index.php/revteatro/issue/view/532/showToc〉. Acesso em: 15 jan. 2017.

LIRA, Fernando (Org.). Jogos para Cenas cômicas. Fortaleza: Grupo Crise 2013.

MOREIRA, J. F. O Encenador dramaturgista e as "duzentas mil" possibilidades dramáticas. Salvador, Bahia: Dissertação de Mestrado PPGAC/UFBA. 2016.

NAZARETH, Carlos Augusto. Trama: um olhar sobre o teatro infantil ontem e hoje. Rio de Janeiro: Lamparina, 2012.

NICOLETE, Adélia. Da Cena ao texto: Dramaturgia em processo colaborativo. São Paulo: Dissertação de Mestrado. ECA/USP. 2005.

PERROTI Edmir. A criança e a produção cultural. In: ZILBERMAN, Regina. (Org.). A produção cultural para crianças. 2. ed. Porto Alegre: Mercado aberto, 1984.

PUPO, Maria Lucia de Souza Barros. Entre o Mediterrâneo e o Atlântico: uma aventura teatral. São Paulo: Perspectiva 2005.

No Reino da Desigualdade: teatro infantil em São Paulo nos anos setenta. São Paulo: Perspectiva; FAPESP, 1991. (Debates; v. 244).

ROMAGNOLI, Marcelo. O Desafio do Teatro para Crianças e Jovens. Revista Banda Mirim 10 anos de Música e Teatro para crianças Ano.1 n.1. São Paulo. 2014. 
ROUBINE, Jean-Jacques. A linguagem da encenação teatral. Rio de Janeiro: Jorge Zahar, 1998. p. 19-80.

SAADI, Fátima. Dramaturgias: Estudo sobre a função do dramaturgista. Revista Questão de Crítica, 2013. Disponível em: . Acesso em: 10 jun. 2017 - A prática do dramaturgo: artigo de Fátima Saadi sobre a sua prática de dramaturg no Teatro do Pequeno Gesto. Revista Questão de crítica, 2008. Disponível em: . Acesso em: 10 jun. 2017.

SINISTERRA, José Sanchis. Da Literatura ao palco: Dramaturgia de Textos Narrativos. São Paulo: É Realizações, 2016.

SPOLIN, Viola. O jogo teatral no Livro do diretor. São Paulo: Perspectiva, 2008.

TELLES, Narciso. Paragens de um artista-docente-docente-pesquisador. In: TELLES, Narciso (Org.). Pesquisa em Artes Cênicas: Textos e Temas. Rio de Janeiro: E-papers. 2012.

Recebido em 28 de junho de 2019

Aceito em 20 de agosto de 2019 